\title{
Quality characteristics of madeleine added with halla gold kiwifruit fermented by lactic acid bacteria
}

\author{
Ji-yeon Ryu ${ }^{1}$, Hyun Jeong Park ${ }^{1}$, Su Lim Lee ${ }^{1}$, So Yae Koh ${ }^{2}$, Ji Hee Lim³ \\ Hyeon A Kim ${ }^{3}$, Somi Kim Cho ${ }^{1,2,4 *}$ \\ ${ }^{1}$ School of Biomaterials Sciences and Technology, College of Applied Life Sciences, SARI, Jeju National University, \\ Jeju 63243, Korea \\ ${ }^{2}$ Interdisciplinary Graduate Program in Advanced Convergence Technology and Science, Jeju National University, Jeju 63243, Korea \\ ${ }^{3}$ Jekiss Co., Ltd., Research Institute, Jeju 63067, Korea \\ ${ }^{4}$ Subtropical/Tropical Organism Gene Bank, Jeju National University, Jeju 63243, Korea
}

\section{골드키위 유산균 발효물을 첨가한 마들렌의 품질 특성}

\author{
류지연 $^{1} \cdot$ 박현정 $^{1} \cdot$ 이수림 ${ }^{1} \cdot$ 고소예 $^{2} \cdot$ 임지희 $^{3} \cdot$ 김현아 $^{3} \cdot$ 김소미 $^{1,2,4 *}$ \\ ${ }^{1}$ 제주대학교 바이오소재공학과, ${ }^{2}$ 제주대학교 차세대융복합과학기술협동과정, \\ ${ }^{3}$ (주)제키스, ${ }^{4}$ 아열대 · 열대생물유전자은행센터
}

\begin{abstract}
Fermented halla gold kiwifruit (FHK) was prepared with Lactobacillus plantarum CK10, a bacterium derived from kimchi. We investigated the quality characteristics and antioxidative activity of madeleine added with FHK. The madeleine dough was prepared by mixing flour, sugar, baking powder, and then followed by adding salt, rum, different amount of the FHK $(0,1$, and $3 \%)$ and butter. The total titratable acidity of madeleine increased significantly with the amounts of added FHK $(p<0.05)$, while the $\mathrm{pH}$ value and total soluble solids showed the reverse trend. The color of madeleine became substantially redder with increasing amounts of FHK $(p<0.05)$, and it appeared darker and less yellow at the same time. The total polyphenol contents of madeleines increased significantly with increasing amounts of FHK $(\mathbf{p}<\mathbf{0 . 0 5})$, but there was little difference in the total flavonoid content. When the antioxidant activities were measured in terms of 2,2-diphenyl-1-picrylhydrazyl (DPPH)- and 2,2'-azino-bis-3-ethylbenzothiazoline6-sulfonic acid-diammonium salt (ABTS)- radical scavenging, both measured activities of madeleines increased dramatically with added FHK in a dose-dependent manner. Our results suggested that the acidity, color, polyphenol content, and antioxidant activities of madeleines can be improved by adding the fermented gold kiwifruit.
\end{abstract}

Key words : antioxidant, fermentation, gold kiwifruit, lactic acid bacteria, madeleine

\section{서 론}

키위는 다래나무과(Acinidiaceae) 다래나무속(Actinidia) 에 속하는 자웅이주의 넝쿨성 낙엽과수로 주로 온대지역에

*Corresponding author. E-mail : phd.kim.somi@gmail.com Phone : 82-64-754-3348, Fax : 82-64-756-3351

Received 27 February 2018; Revised 29 March 2018; Accepted 6 April 2018

Copyright (c) The Korean Society of Food Preservation. All rights reserved.
서 자라며, 국내에서는 주로 남해안 일대와 제주도에서 재 배되고 있다(1,2), 이 중에서 '한라골드'는 국내에서 육성되 고 보급된 골드키위 품종으로서 과육색은 밝은 황색을 나타 내며 과즙이 많고 부드럽다. 또한, 나무 가지에 털이 없으며 당도가 높은 특성을 지니고 있다(3). 일반적으로 키위는 퀴닌산, 말산, 시트르산 등 유기산을 함유하여 특유의 풍미 를 가지며, 비타민 $\mathrm{C}$ 가 풍부하고 클로로필, 카로티노이드와 같은 건강에 유익한 다양한 생리활성물질을 함유하고 있다 (4). 또한, 화학성분과 항산화 활성(2), 신경세포 보호 효과 (4), tyrosinase 활성저해 및 항균활성 효과(5), 위암세포 증 
식 억제 및 연육효과(6), 변비개선에 관한 연구(7) 등에 대해 보고되고 있다. 한편 유산균 발효는 유산균에 의해 유용한 물질을 생산하는 전통 식품 발효법으로써 항산화, 항암 등 건강상의 이점을 준다고 알려져 있다(8). 최근 유산균 발효 를 이용해 저장성, 영양 품질 및 생리활성을 높이는 연구가 활발히 진행되고 있다 $(9,10)$. 이와 같이 유산균에 대한 연구 는 활발히 보고되고 있으나, 키위 유산균 발효물을 이용한 제품개발에 대한 연구는 미비한 실정이다.

마들렌은 제과제품 중 제조가 간단하며, 달걀이나 우유 가 혼합되어 영양가가 풍부하다(11). 또한 식감이 연하고 부드러워 젊은 여성 또는 노인 등의 주된 간식으로 애용되 고 있으며(12), 보관도 쉬워 시중에서 선물용으로 많이 판매 되고 있다. 그러나 시중의 판매되는 마들렌은 바닐라 향 또는 코코아 가루를 첨가한 제품 등으로 종류가 한정적이다 (13). 기능성 마들렌에 관한 연구로는 복숭아즙 첨가 마들렌 의 품질 특성(11), 유기농 인삼 잎을 첨가한 마들렌의 품질 특성(12), 렌틸콩 분말을 첨가한 마들렌의 품질 특성(13)과 솔잎분말과 생즙을 첨가한 쌀 마들렌의 항산화성과 품질 특성(14) 등이 있다.

본 연구에서는 골드키위를 유산균을 이용하여 발효하였 으며, 골드키위 유산균 발효물을 첨가하여 마들렌을 제조 하고 이에 대한 품질 특성과 항산화 활성을 분석하였다. 이를 통해 골드키위 유산균 발효물을 첨가한 마들렌 제품 개발 가능성에 대해 확인하고자 하였다.

\section{재료 및 방법}

\section{실험재료 및 시약}

본 연구에서 재료로 사용한 골드키위 퓨레는 (주)제키스 에서 2017년 1월 제공받아 실험에 사용하였다. FolinGocalteu's reagent, Gallic acid, Rutin, 2,2-diphenyl-1-picrylhydrazyl (DPPH), 2,2'-azino-bis-3-ethylbenzothiazoline-6-sulfonic aciddiammonium salt(ABTS)은 Sigma Chemical Co.(St. Louis, $\mathrm{MO}, \mathrm{USA}$ )에서 구입하여 사용하였으며, MRS 배지는 $\mathrm{BD}$ Difco(Sparks, MD, USA)에서 구입하여 사용하였다.

\section{사용 균주 및 배양 조건}

실험에 사용한 균주는 오이소박이김치(Oisobaki)로부터 유래한 Lactobacillus plantarum CK10으로 경기대학교 식품 생물공학과 이종훈 교수로부터 제공받아 사용하였다(15). L. plantarum CK10 균주는 MRS 배지를 이용하여 24시간동 안 $30^{\circ} \mathrm{C}, 100 \mathrm{rpm}$ 조건으로 배양하였다.

\section{골드키위 유산균 발효물 제조}

골드키위 배지는 Campanella 등(16)의 방법을 변형하여 수행하였다. 골드키위 파우더 $5 \%(\mathrm{v} / \mathrm{v})$ 와 분말이스트액기
스 $2 \%(\mathrm{v} / \mathrm{v})$ 를 증류수와 균질화한 후, $1 \mathrm{~N} \mathrm{NaOH}$ 를 이용하여 $\mathrm{pH} 6.00 \pm 0.50$ 로 조정하였다. 그 후 autoclave를 이용하여 $121^{\circ} \mathrm{C}, 15$ 분 조건으로 멸균하였다. L. plantarum CK10은 접종 전 $\mathrm{MRS}$ 배지에서 2회 계대 배양하였으며, $600 \mathrm{~nm}$ 파장 에서 $\mathrm{OD}$ 값이 0.6 일 때 $(7.00 \pm 0.50 \log \mathrm{CFU} / \mathrm{mL})$ 골드키위 배지에 $1 \%(\mathrm{v} / \mathrm{v})$ 접종하였다. 발효는 $30^{\circ} \mathrm{C}, 100 \mathrm{rpm}$ 조건으 로 7일간 수행하였다.

\section{골드키위 유산균 발효물 첨가 마들렌 제조}

마들렌은 밀가루, 버터, 달걀, 설탕 등을 주원료로 제조하 였으며 각각의 재료의 배합비율은 Table 1 과 같다. 골드키 위 유산균 발효물이 첨가된 마들렌 제조 시에는 모든 재료 를 동일하게 첨가하되, 골드키위 유산균 발효물 첨가량에 해당하는 양만큼 밀가루를 감량하여 첨가하였다. 배합비율 에 맞추어 계량한 각 재료를 이용하여 먼저 밀가루, 설탕, 베이킹파우더를 반죽기(KitchenAid K45SSEWH, KitchenAid, Benton, $\mathrm{CA}, \mathrm{USA}$ )에 넣어 혼합하고 계란을 3회에 나누어 혼합한 뒤 소금, 럼주, 골드키위 유산균 발효물을 추가하고 중탕한 버터를 3회에 나누어 넣어 반죽하였다. 준비된 반죽 을 마들렌 틀에 담아 $175^{\circ} \mathrm{C}$ 의 오븐(Electric convection oven, EKA, Borgoricco PD, Italy)에서 14분간 구워 마들렌을 제조 하였다.

Table 1. Formula for the manufacturing of madeleine added with fermented halla gold kiwifruit

\begin{tabular}{cccc}
\hline \multirow{2}{*}{ Experimental factor (\%) } & \multicolumn{3}{c}{ Samples $^{1)}$} \\
\cline { 2 - 4 } & Control & FHK1 & FHK3 \\
\hline Flour & 26 & 25 & 23 \\
Fermented halla gold kiwifruit & 0 & 1 & 3 \\
Butter & 26 & 26 & 26 \\
Sugar & 23 & 23 & 23 \\
Baking powder & 0.1 & 0.1 & 0.1 \\
Salt & 1 & 1 & 1 \\
Egg & 23 & 23 & 23 \\
Rum & 2 & 2 & 2 \\
\hline
\end{tabular}

${ }^{1)}$ Control, madeleine without added fermented halla gold kiwifruit; FHK1, madeleine added with fermented halla gold kiwifruit 1\%; FHK3, madeleine added with fermented halla gold kiwifruit $3 \%$.

\section{$\mathrm{pH}$, 산도 및 당도}

$\mathrm{pH}$ 는 Orion 3star benchtop $\mathrm{pH}$ meter(Thermo Scientific Inc. Waltham, MA, USA)를 이용하여 측정하였다. 총산도는 발효물 $10 \mathrm{~mL}$ 에 $0.1 \mathrm{~N} \mathrm{NaOH}$ 를 이용하여 $\mathrm{pH} 8.2$ 가 될 때까 지 적정하였으며 적정에 소비되는 $0.1 \mathrm{~N} \mathrm{NaOH}$ 의 소모량을 젖산 함량으로 환산하여 계산하였다. 총당도는 brix refractometer(PAL-1, Atago, Tokyo, Japan)을 이용하여 측정 하였다. 
색 도

마들렌의 색도 측정을 위해 색차계를 사용하여 Hunter's $\mathrm{L}$ 값(명도), $\mathrm{a}$ 값(적색도), $\mathrm{b}$ 값(황색도) 및 $\Delta \mathrm{E}$ 값을 측정하였 다. 모든 시료에 대하여 3회 이상 반복 측정하여 평균값으로 나타내었다.

\section{총 폴리페놀 함량}

총 폴리페놀 함량은 Cheung 등(17)의 방법을 약간 변형하 여 증류수 $1.375 \mathrm{~mL}$ 에 $125 \mu \mathrm{L}$ 의 시료를 넣은 후 $0.5 \mathrm{~mL}$ Folin-Ciocalteu's 시약을 넣고 4 분 후에 $1 \mathrm{~mL}$ 의 $\mathrm{Na}_{2} \mathrm{CO}_{3}$ 를 가한 다음 상온에서 30 분 동안 정치하여 반응시켰다. 그 후 분광광도계(Sunrise, Tecan, Salzburg, Austria)를 이용하 여 $700 \mathrm{~nm}$ 에서 흡광도를 측정하였다. 함량은 $\mathrm{mg}$ gallic acid equivalents(GAE)/g dry weight로 나타내었다.

\section{총 플라보노이드 함량}

총 플라보노이드 함량은 Zhishen 등(18)의 방법을 변형하 여 측정하였다. 증류수 $80 \mu \mathrm{L}$ 에 시료 $40 \mu \mathrm{L}$ 를 넣은 후 $5 \%$ $\mathrm{NaNO}_{2} 6 \mu \mathrm{L}$ 를 첨가하여 5 분간 반응시킨 후 $10 \% \mathrm{AlCl}_{3}$ $12 \mu \mathrm{L}$ 를 혼합하여 6 분간 반응시킨 다음 $1 \mathrm{~N} \mathrm{NaOH} 40 \mu \mathrm{L}$ 를 첨가한다. 그 후 증류수 $42 \mu \mathrm{L}$ 를 넣고 앙금이 생기지 않도록 잘 섞어준 후 분광광도계(Sunrise, Tecan, Salzburg, Austria) 를 이용하여 $510 \mathrm{~nm}$ 에서 흡광도를 측정하였다. 함량은 $\mathrm{mg}$ rutin equivalents(RE)/g dry weight로 나타내었다.

\section{$\mathrm{DPPH}$ 라디칼 소거 활성}

$\mathrm{DPPH}$ 라디칼 소거 활성은 기존에 보고된 방법 $(19,20)$ 을 토대로 하여 수행하였다. DPPH 라디칼 용액은 DPPH를 $200 \mu \mathrm{M}$ 로 에탄올에 용해시켜 준비하였고, 96-well plate에 시료를 농도별로 $40 \mu \mathrm{L}$ 씩 분주하고 $200 \mu \mathrm{M} \mathrm{DPPH}$ 라디칼 용액 $160 \mu \mathrm{L}$ 를 첨가한 후 30 분간 $37^{\circ} \mathrm{C}$ incubator에서 반응시 켰다. 반응이 끝나면 분광광도계(Sunrise, Tecan, Salzburg, Austria)를 이용하여 $517 \mathrm{~nm}$ 에서 흡광도를 측정하였다. 양 성대조군으로는 catechin을 사용하였다.

$$
\mathrm{DPPH} \text { radical scavenging activity }(\%)=\left(1-\frac{\text { 시료의 흡광도 }}{\text { 대조구의 흡광도 }}\right) \times 100
$$

\section{ABTS 라디칼 소거 활성}

$\mathrm{ABTS}$ 라디칼 소거 활성은 기존에 보고된 방법(21)을 변형하여 수행하였으며, ABTS 라디칼 용액은 $7 \mathrm{mM} \mathrm{ABTS}$ 와 $2.45 \mathrm{mM} \mathrm{K}_{2} \mathrm{~S}_{2} \mathrm{O}_{8}$ 를 혼합해 20시간 동안 암소에 보관하여 준비하였으며, $\mathrm{OD}$ 값이 $0.700 \pm 0.005$ 에 도달하게 증류수로 희석하여 사용하였다. 큐벳에 $900 \mu \mathrm{L}$ ABTS 라디칼 용액과 $100 \mu \mathrm{L}$ 시료를 혼합하여 실온에서 2분간 반응시킨 후, 분광 광도계(UV1800, Shimadzu, Kyoto, Japan)를 이용하여 734 $\mathrm{nm}$ 에서 흡광도를 측정하였다. 양성대조군으로는 $\mathrm{a}$ -tocopherol을 사용하였다.

ABTS radical scavenging activity $(\%)=\left(1-\frac{\text { 시료의 흡광도 }}{\text { 대조구의 흡광도 }}\right) \times 100$

\section{통계처리}

모든 실험은 3 회 반복 수행하여 평균치와 표준편차로 나타내었으며, 실험군 간의 유의성 검증 및 상관성 분석은 SPSS(Statistical package for social sciences, SPSS Inc, Chicago, IL, USA) software(version 18.0)를 이용하여 실시 하였으며, 유의성 검증의 경우 ANOVA one way로 분석한 뒤 Least significant difference(LSD) test를 이용하여 $a=0.05$ 수준에서 유의성 검정을 수행하였다.

\section{결과 및 고찰}

\section{마들렌의 품질 평가}

골드키위 유산균 발효물을 $1,3 \%$ 첨가하여 마들렌을 제 조하였으며, 제조한 마들렌의 단면도는 Fig. 1 과 같다. 마들 렌의 $\mathrm{pH}$, 총산도, 총당도는 Table 2 와 같다. 마들렌의 $\mathrm{pH}$ 는 대조군이 7.39 \pm 0.09 로 가장 높았으며, 골드키위 유산균 발 효물을 첨가할 경우 각각 $5.81 \pm 0.10,4.65 \pm 0.02$ 로 유의적으 로 감소하는 결과를 보였다( $<<0.05)$. 산도의 경우 대조군이 $0.03 \pm 0.00 \%$, 골드키위 유산균 발효물을 첨가할 경우 각각 $0.09 \pm 0.00,0.33 \pm 0.00 \%$ 으로 첨가비율이 증가할수록 $\mathrm{pH}$ 는 감소하고 산도가 증가하는 것을 나타났다. 이는 Yang과 Hong(22)의 연구에서 유산균 발효에 의해 유기산이 생산되 고 이로 인해 $\mathrm{pH}$ 가 감소하여 발효물을 식품에 첨가하였을 때 $\mathrm{pH}$ 가 감소하고 산도가 증가한다는 결과와 유사한 경향 을 나타냈다. 골드키위 유산균 발효물을 첨가한 마들렌의 당도는 브릭스 당도를 이용하여 측정하였다. 대조군의 당 도는 $3.20 \pm 0.00{ }^{\circ} \mathrm{Brix}$, 골드키위를 첨가한 마들렌의 경우 첨가비율에 따라 각각 $2.40 \pm 0.00,2.27 \pm 0.06{ }^{\circ} \mathrm{Brix}$ 로 첨가비 율이 증가할수록 유의적으로 감소하는 결과를 보였다.

Table 2. Changes of $\mathrm{pH}$, TTA, and TSS of madeleine added with fermented halla gold kiwifruit

\begin{tabular}{cccc}
\hline Sample $^{1)}$ & $\mathrm{pH}$ & $\mathrm{TTA}^{2)}(\%)$ & TSS $^{3)}\left({ }^{\circ}\right.$ Brix $)$ \\
\hline Control & $7.39 \pm 0.09^{4) 25}$ & $0.03 \pm 0.00^{\mathrm{a}}$ & $3.20 \pm 0.00^{\mathrm{a}}$ \\
FHK1 & $5.81 \pm 0.10^{\mathrm{b}}$ & $0.09 \pm 0.00^{\mathrm{b}}$ & $2.40 \pm 0.00^{\mathrm{b}}$ \\
FHK3 & $4.65 \pm 0.02^{\mathrm{c}}$ & $0.33 \pm 0.00^{\mathrm{c}}$ & $2.27 \pm 0.06^{\mathrm{c}}$ \\
\hline
\end{tabular}

${ }^{1)}$ Control, madeleine without added fermented halla gold kiwifruit; FHK1, madeleine added with fermented halla gold kiwifruit 1\%; FHK3, madeleine added with fermented halla gold kiwifruit $3 \%$.

${ }^{2}$ TTA, total titratable acidity.

${ }^{3)}$ TSS, total soluble solids.

${ }^{4)}$ Values are Mean \pm SD $(\mathrm{n}=3)$.

${ }^{5}$ Means with different letters within a column differ significantly $(\mathrm{p}<0.05)$. 

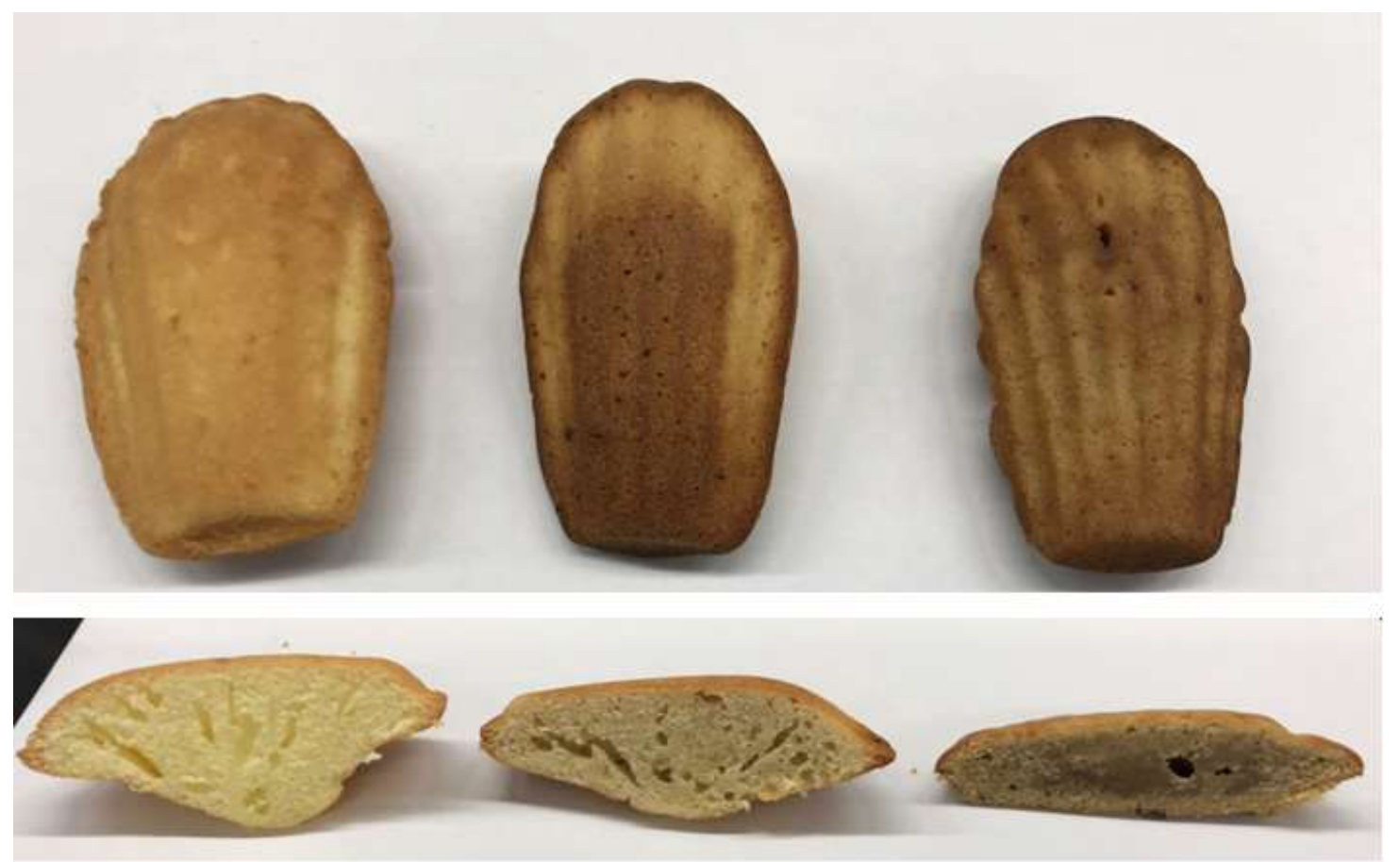

Control FHK1

\section{FHK3}

Fig. 1. Front and cross sections of madeleine added with fermented halla gold kiwifruit (FHK).

Control, madeleine without added fermented halla gold kiwifruit; FHK1, madeleine added with fermented halla gold kiwifruit 1\%; FHK3, madeleine added with fermented halla gold kiwifruit $3 \%$.

(p<0.05). Liu 등(23)의 연구에서 유산균 발효 시 당 함량이 감소하고 펙틴이 분해되면서 총당도가 감소한다고 보고하 였으며 본 실험에서 제조된 마들렌 역시 골드키위 유산균 발효물 첨가비율에 따라 당도가 낮아지는 경향을 나타냈 다. 또한 유산균 발효에 의해 생성된 유기산은 발효물의 $\mathrm{pH}$ 를 저하시켜 오염을 방지할 수 있다는 보고(24)를 통해 골드키위 유산균 발효물을 첨가할 경우 마들렌의 오염을 방지할 수 있으며 저장성을 향상시킬 수 있을 것으로 사료 된다.

\section{마들렌의 색도}

골드키위 유산균 발효물을 첨가한 마들렌의 색도는 Table 3 과 같다. 마들렌의 명도를 나타내는 $\mathrm{L}$ 값은 대조군이 $42.65 \pm 1.35$, 골드키위 유산균 발효물을 $1,3 \%$ 첨가한 마들 렌이 각각 $41.22 \pm 1.56,41.67 \pm 0.73$ 으로 대조군과 비교하여 $\mathrm{L}$ 값이 감소하였다. 이러한 $\mathrm{L}$ 값의 감소는 $\mathrm{Lim}$ 등(11)의 연구, $\mathrm{Kim}$ 등(12)의 연구와 $\mathrm{Bae}$ 등(13)의 연구에서 첨가에 의해 마들렌의 L 값이 저하된다는 보고와 유사한 결과였다. 또한, 이전 연구에서 $\mathrm{L}$ 값의 감소는 오븐에서 구울 때 열에 의해 설탕, 아미노산의 변화, 그 외의 물질들의 혼합이 원인 이라 보고하였다(25). 골드키위 유산균 발효물을 첨가하였 을 때 적색도를 나타내는 a 값이 발효물 첨가에 따라 감소하
는 것을 확인할 수 있었으며, 황색도를 나타내는 b 값이 대조군 $0.52 \pm 0.11$ 과 비교하여 발효물을 $1,3 \%$ 첨가한 마들 렌에서 $1.50 \pm 0.30,3.19 \pm 0.28$ 으로 증가하였다. 이러한 결과 는 이전 연구(11-13)에서 첨가에 따라 $\mathrm{a}$ 값이 증가하고 $\mathrm{b}$ 값이 감소한다는 결과와 다르게 나타났다. 그러나 제품에 첨가하는 재료가 가지고 있는 색소에 의해 최종 제품의 색도에 영향을 준다는 보고(26)에서와 같이 골드키위가 가 진 색도에 의해 첨가량에 따른 색의 차이를 보인 것으로 생각된다. $\Delta \mathrm{E}$ 값은 전체적인 색차를 표현하는 값으로 1.5 이상의 값을 보일 경우 색차가 감지된다는 것을 나타낸다.

Table 3. Hunter's color value of madeleine added with fermented halla gold kiwifruit

\begin{tabular}{ccccc}
\hline Sample $^{1)}$ & L (lightness) & $\mathrm{a}$ (redness) & $\mathrm{b}$ (yellowness) & $\Delta \mathrm{E}^{2)}$ \\
\hline Control & $42.65 \pm 1.35^{3) \mathrm{a} 4}$ & $0.69 \pm 0.02^{\mathrm{a}}$ & $0.52 \pm 0.11^{\mathrm{a}}$ & 0.00 \\
FHK1 & $41.22 \pm 1.56^{\mathrm{a}}$ & $0.48 \pm 0.01^{\mathrm{b}}$ & $1.50 \pm 0.30^{\mathrm{b}}$ & 1.75 \\
FHK3 & $41.67 \pm 0.73^{\mathrm{a}}$ & $-0.07 \pm 0.01^{\mathrm{c}}$ & $3.19 \pm 0.28^{\mathrm{c}}$ & 1.83 \\
\hline
\end{tabular}

${ }^{1)}$ Control, madeleine without added fermented halla gold kiwifruit; FHK1, madeleine added with fermented halla gold kiwifruit 1\%; FHK3, madeleine added with fermented halla gold kiwifruit $3 \%$.

${ }^{2)} \Delta \mathrm{E}=\sqrt{\triangle L^{2}+\triangle a^{2}+\triangle b^{2}}$.

${ }^{3)}$ Values are Mean $\pm \mathrm{SD}(\mathrm{n}=3)$.

${ }^{4}$ Means with different letters within a column differ significantly $(\mathrm{p}<0.05)$. 
골드키위 유산균 발효물을 $1,3 \%$ 첨가한 마들렌에서 각각 $1.75,1.83$ 의 값을 보여 색차가 감지된다는 것을 확인할 수 있었으며, 첨가량이 많아질수록 차이가 나타남을 확인 할 수 있었다.

\section{총 폴리페놀 및 플라보노이드 함량}

골드키위 유산균 발효물을 첨가한 마들렌의 총 폴리페놀 및 플라보노이드 함량은 Table 4와 같다. 총 폴리페놀 함량 은 대조군에서 $0.14 \pm 0.01 \mathrm{mg} \mathrm{GAE} / \mathrm{g}$ 으로 나타났으며, 골드 키위 유산균 발효물을 $1,3 \%$ 첨가한 마들렌에서는 각각 $0.20 \pm 0.03,0.31 \pm 0.04 \mathrm{mg} \mathrm{GAE} / \mathrm{g}$ 으로 대조군과 비교하여 약 $1.4,2.2$ 배 증가하였다. 이를 통해 첨가비율이 증가할수 록 총 폴리페놀 함량이 증가하는 것을 확인할 수 있었다. 총 플라보노이드 함량의 경우 대조군에서 $0.03 \pm 0.01 \mathrm{mg}$ $\mathrm{RE} / \mathrm{g}$ 으로 나타났으며, 골드키위 유산균 발효물을 $1,3 \%$ 첨가한 마들렌에서는 각각 $0.03 \pm 0.00,0.04 \pm 0.01 \mathrm{mg} \mathrm{RE} / \mathrm{g}$ 로 대조군과 유사한 함량을 나타냈다. 이는 $\mathrm{Kim}$ 등(14)의 연구 에서 솔잎분말과 생즙을 첨가한 쌀 마들렌에서는 첨가에 따라 총 폴리페놀 함량이 높아진다는 결과와 유사하였으 나, 총 플라보노이드 함량이 증가한다는 결과와는 다른 경 향을 보였다. 폴리페놀은 식물계에서 널리 분포되어 있는 대사산물로 환원제, 수소 공여체 및 활성 산소 소거제 등 다양한 항산화 활성과 생리활성에 작용하게 된다. 또한 플 라보노이드계와 비플라보노이드계로 나누어지며 플라보 노이드는 페놀성 화합물의 주된 성분으로 일반적으로 총 플라보노이드 함량과 총 폴리페놀 함량은 밀접한 상관관계 를 있다고 보고되었다(27). 그러나 골드키위 유산균 발효물 을 첨가한 마들렌의 경우 폴리페놀 함량은 증가하지만 플라 보노이드 함량에는 차이가 없는 것을 통해 플라보노이드계 보다는 비플라보노이드계 폴리페놀의 함량이 높아진 것으 로 사료된다.

Table 4. Total polyphenol and flavonoid contents of madeleine added with fermented halla gold kiwifruit

\begin{tabular}{ccc}
\hline Sample $^{1)}$ & $\mathrm{TPC}^{2)}\left(\mathrm{mg} \mathrm{GAE}^{3} / \mathrm{g}\right)$ & $\mathrm{TFC}^{4)}\left(\mathrm{mg} \mathrm{RE}^{5} / \mathrm{g}\right)$ \\
\hline Control & $0.14 \pm 0.01^{(\mathrm{a}) \mathrm{T}}$ & $0.03 \pm 0.01^{\mathrm{a}}$ \\
FHK1 & $0.20 \pm 0.03^{\mathrm{b}}$ & $0.03 \pm 0.00^{\mathrm{a}}$ \\
FHK3 & $0.31 \pm 0.04^{\mathrm{c}}$ & $0.04 \pm 0.01^{\mathrm{a}}$ \\
\hline
\end{tabular}

${ }^{1)}$ Control, madeleine without added fermented halla gold kiwifruit; FHK1, madeleine added with fermented halla gold kiwifruit $1 \%$; FHK3, madeleine added with fermented halla gold kiwifruit $3 \%$.

${ }^{2)} \mathrm{TPC}$, total polyphenol contents.

${ }^{3)} \mathrm{GAE}$, gallic acid equivalent.

${ }^{4)} \mathrm{TFC}$, total flavonoid contents.

${ }^{5} \mathrm{RE}$, rutin equivalent.

${ }^{6)}$ Values are Mean \pm SD $(n=3)$.

${ }^{7)}$ Means with different letters within a column differ significantly $(\mathrm{p}<0.05)$.

\section{$\mathrm{DPPH}$ 라디칼 소거 활성}

항산화 물질의 경우 인체 내에서 지질, 단백질과 결합하
여 노화를 일으키는 자유 라디칼을 상쇄, 환원하여 자유 라디칼을 소거한다고 알려져 있다. DPPH 라디칼은 자유라 디칼 중 하나로 ascorbic acid, butylated hydroxy anisole (BHA) 등과 같은 항산화 물질과 만나면 노란색으로 환원되 는 특징을 갖는다. DPPH 라디칼과 항산화 물질이 만나면 나타나는 색 변화를 이용하여 항산화 활성을 평가하는 지표 로 많은 연구에서 활용하고 있다(28). 골드키위 유산균 발효 물을 첨가한 마들렌의 DPPH 라디칼 소거 활성은 Fig. 2와 같다. 대조군을 제외한 모든 추출물에서 $\mathrm{DPPH}$ 라디칼 소거 활성이 농도 의존적으로 증가하였다. 대조군 농도 $12.5,25$, $50 \mathrm{mg} / \mathrm{mL}$ 에서 $\mathrm{DPPH}$ 라디칼 소거 활성은 각각 $2.17,2.14$, $6.51 \%$ 였으나, 골드키위 유산균 발효물을 $1 \%$ 첨가 시 $\mathrm{DPPH}$ 라디칼 소거 활성은 10.51-31.09\%, 골드키위 유산균 발효물 을 3\% 첨가 시 $\mathrm{DPPH}$ 라디칼 소거 활성은 21.36-62.18\%로, 골드키위 유산균 발효물 첨가비율에 따라 DPPH 라디칼 소거 활성이 증가하였다. 이는 $\mathrm{Bae}$ 등(13)의 연구와 $\mathrm{Kim}$ 등(14)의 연구에서 각각 렌틸콩 분말과 솔잎 분말의 첨가량 을 높일수록 마들렌의 DPPH 라디칼 소거 활성이 증가한다 는 보고와 유사한 결과였다. 키위에 함유된 quercetin, pyrogallol, ferulic acid 등과 같은 폴리페놀 성분과 발효에 의해 생산된 페놀 화합물과 같은 대사산물이 $\mathrm{DPPH}$ 라디칼 소거 활성에 기여한 것으로 사료된다.

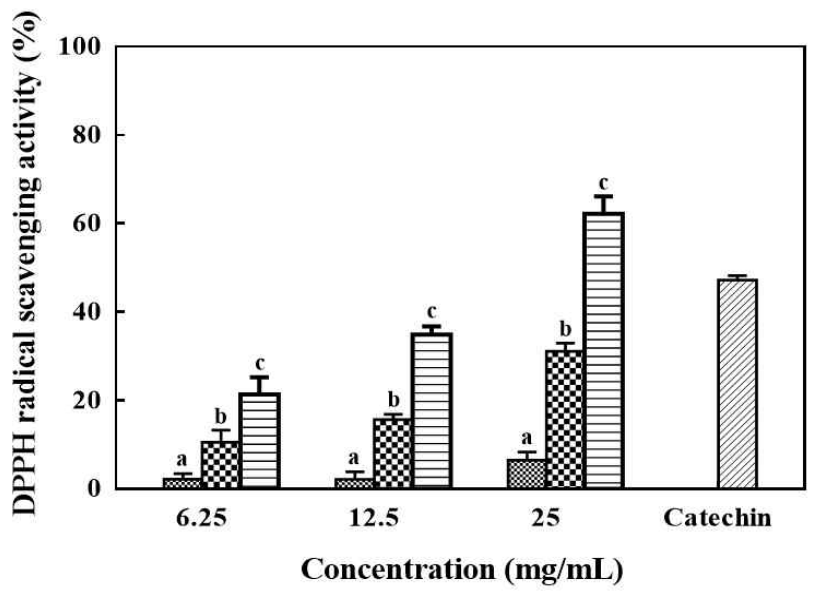

Fig. 2. DPPH radical scavenging activity of madeleine added with fermented halla gold kiwifruit.

Control, madeleine without added fermented halla gold kiwifruit; $\otimes$ FHK1, madeleine added with fermented halla gold kiwifuit $1 \%$; $\boxminus$, FHK3, madeleine added with fermented halla gold kiwifruit $3 \%$.

The appropriate amount of catechin $(200 \mu \mathrm{M})$ was used as a positive control. Values are Mean $\pm \mathrm{SD}(\mathrm{n}=3)$. Means with different letters within a column differ significantly $(\mathrm{p}<0.05)$.

\section{$\mathrm{ABTS}$ 라디칼 소거 활성}

$\mathrm{ABTS}$ 라디칼은 청록색을 띠는 라디칼로 항산화 물질과 만나면 하늘색으로 탈색되는 특징을 가지며 hydrogendonating antioxidants와 chain breaking antioxidants를 모두 측정할 수 있다(28). 골드키위 유산균 발효물을 첨가한 마들 
렌의 ABTS 라디칼 소거 활성은 Fig. 3 과 같다. 모든 추출물 에서 $\mathrm{ABTS}$ 라디칼 소거 활성이 농도 의존적으로 증가하였 다. 대조군 농도 $6.25,12.5,25 \mathrm{mg} / \mathrm{mL}$ 에서 $\mathrm{ABTS}$ 라디칼 소거 활성은 4.42-17.00\% 였으나, 골드키위 유산균 발효물 을 $1 \%$ 첨가 시 $\mathrm{ABTS}$ 라디칼 소거 활성은 $11.02-36.75 \%$ 골드키위 유산균 발효물 3\% 첨가 시 $\mathrm{ABTS}$ 라디칼 소거 활성은 19.85-61.85\%로 골드키위 유산균 발효물 첨가비율 이 증가할수록 $\mathrm{ABTS}$ 라디칼 소거 활성이 증가하였다. 이는 이전 연구에서 DPPH 라디칼 소거 활성과 ABTS 라디칼 소거 활성이 높은 상관관계를 보인다는 보고(29)와 유사한 경향을 나타냈다. 골드키위 유산균 발효물은 마들렌의 항 산화 활성 증가에 기여하며 이러한 활성 증가를 통해 이후 여러 질병 예방에 도움이 되는 기능성 식품으로 활용 가능 할 것으로 사료된다.

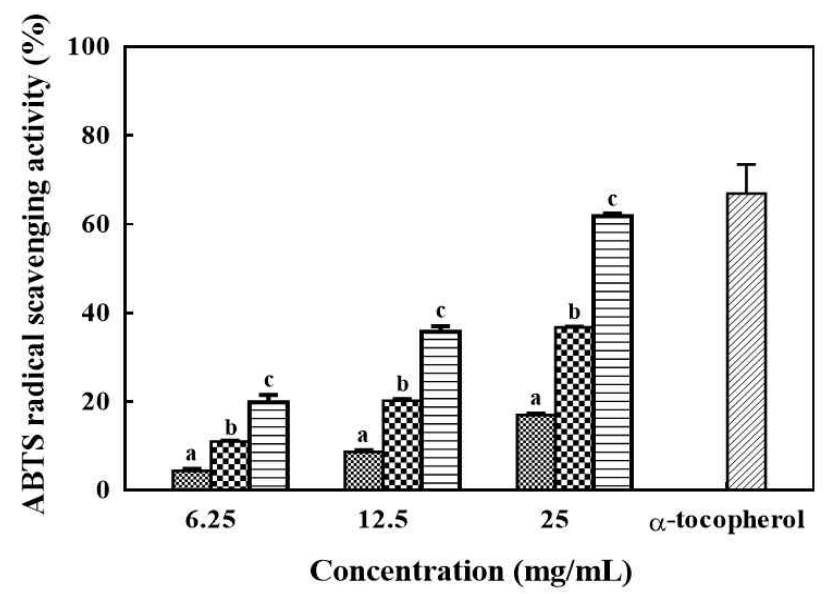

Fig. 3. ABTS radical scavenging activity of madeleine added with fermented halla gold kiwifruit.

- Control, madeleine without added fermented halla gold kiwifruit; $\boldsymbol{\otimes}$ FHK1, madeleine added with fermented halla gold kiwifruit 1\%; $\boxminus$, FHK3, madeleine added with fermented halla gold kiwifruit $3 \%$.

The appropriate amount of a-tocopherol $(200 \mu \mathrm{M})$ was used as a positive control. Values are Mean $\pm S D(n=3)$. Means with different letters within a column differ significantly $(\mathrm{p}<0.05)$.

\section{요 약}

본 연구에서는 김치에서 유래한 Lactobacillus plantarum $\mathrm{CK} 10$ 을 이용하여 골드키위를 발효하고, 골드키위 유산균 발효물을 이용하여 마들렌을 제조하였으며 골드키위 유산 균 발효물 첨가에 따른 마들렌의 품질 특성 및 항산화 활성 을 확인하였다. 골드키위 유산균 발효물 첨가량이 증가할 수록 $\mathrm{pH}$, 총당도가 감소하였으며, 산도는 증가하였다. 색도 측정 결과 골드키위 유산균 발효물을 첨가한 마들렌이 대조 군과 비교하여 $\mathrm{L}$ 값과 $\mathrm{a}$ 값이 감소하고 $\mathrm{b}$ 값이 증가하는 결과를 보였다. 총 폴리페놀 함량은 골드키위 유산균 발효 물 첨가비율이 증가함에 따라 각각 $1.4,2.2$ 배 증가하였으
며, 총 플라보노이드 함량의 경우 유의적 차이가 나타나지 않았다. DPPH 라디칼 소거 활성은 골드키위 유산균 발효물 첨가 시 각각 10.51-31.09, 21.36-62.18\%로 대조군 2.17$6.51 \%$ 과 비교하여 높은 활성을 보였으며, ABTS 라디칼 소거 활성 역시 $1.02-36.75,19.85-61.85 \%$ 로 대조군 4.42$17.00 \%$ 과 비교하여 높은 활성을 보였다. 따라서 골드키위 유산균 발효물 첨가비율이 높을수록 품질 및 항산화 활성이 향상되는 것을 확인하였으며, 향후 골드키위 유산균 발효 물은 마들렌 및 다양한 기능성 식품 개발에 적용 가능할 것으로 사료된다.

\section{감사의 글}

본 연구는 산업통상자원부와 한국산업기술진흥원의 2017년 지역주력 산업육성(R\&D)의 연구결과입니다.

\section{References}

1. Jeong CH, Lee WJ, Bae SH, Choi SG (2007) Chemical components and antioxidative activity of Korean gold kiwifruit. J Korean Soc Food Sci Nutr, 36, 859-865

2. Oh HJ, Jeon SB, Kang HY, Yang YJ, Kim SC, Lim SB (2011) Chemical composition and antioxidative activity of kiwifruit in different cultivars and maturity. J Korean Soc Food Sci Nutr, 40, 343-349

3. Kim SC, Song EY, Kim CH (2012) A new kiwifruit variety, 'halla gold' with high soluble solids content and early harvesting. Korean J Hortic Sci Technol, 30, 334-337

4. Heo BG, Park YJ, Kim TC, Park YS, Cha WM, Kim HJ, Ahn JS, Baek SH, Park SM (2009) Tyrosinase inhibition and anti-microbial activities of kiwifruits extract. J Life Sci Nat Res, 32, 107-119

5. Heo BG, Park YS, Park YJ, Jang HG, Choi JR, Cho JY (2010) Hyperplasia inhibition activity of classified kiwifruits against gastric cancer cells and its meat softening activity. J Life Sci Nat Res, 32, 25-36

6. Kim DG, Jin YG, Jin JY, Kim SC, Kim SC, Han CH, Lee YJ (2011) Effects of the Actindia chinensis on loperamide-induced constipation in rat. Korean J Plant Resour, 24, 61-68

7. Lee HY, Seo WT, Jeong SH, Hwang CE, Ahn MJ, Lee AR, Shin JH, Lee JY, Jo HK, Cho KM (2016) Physicochemical characteristics and volatile flavor compounds of produced mixture wine with kiwi and 
permission fruits using wild yeast, Saccharomyces cerevisiae Y28. Korean J Microbiol, 52, 98-109

8. Fessard A, Kapoor A, Patche J, Assemat S, Hoarau M, Bahorun T, Remize F (2017) Lactic fermentation as an efficient tool to enhance the antioxidant activity of tropical fruit juices and teas. Microorganisms, 5, 1-20

9. Bhat R, Suryanarayana LC, Chandrashekara KA, Krishnan P, Kush A, Ravikumar P (2015) Lactobacillus plantarum mediated fermentation of Psidium guajava $\mathrm{L}$. fruit extract. J Biosci Bioeng, 119, 430-432

10. Woo SM, Choi IW, Jeong YJ (2006) Effect of kiwi wine and kiwi liqueur on sensory characteristics as cooking alcohol. Korean J Food Preserv, 13, 519-523

11. Lim YT, Kim DH, Ahn JB, Choi SH, Han GP, Kim GH, Jang KI (2012) Quality characteristics of madeleine with peach(Prunus persica L. Batsch) juice. Korean J Food Nutr, 25, 664-670

12. Kim KP, Kim KH, Yooh HS (2016) Quality characteristics of madeleine added with organic ginseng (Panax ginseng C. A. Meyer) leaf. J Korean Soc Food Sci Nutr, 45, 717-722

13. Bae DB, Kim KH, Yook HS (2016) Quality characteristics of madeleine added with lentil (Lens culinaris) powder. J Korean Soc Food Sci Nutr, 45, 1816-1822

14. Kim WJ, Kim JM, Cheong HS, Huh YR, Shin MS (2014) Antioxidative activity and quality characteristics of rice madeleine added with pine needle powder and extract. J Korean Soc Food Sci Nutr, 43, 446-453

15. Kwon TY, Shim SM, Lee JH (2008) Characterization of lactobacilli with tannase activity isolated from Kimchi. Food Sci Biotechnol, 17, 1322-1326

16. Campanella D, Rizzello CG, Fasciano C, Gambacorta G, Pinto D, Marzani B, Scarano N, Angelis MD, Gobbetti M (2017) Exploitation of grape marc as functional substrate for lactic acid bacteria and bifidobacteria growth and enhanced antioxidant activity. Food Microbiol, 65, 25-35

17. Cheung LM, Cheung PCK, Ooi VEC (2003) Antioxidant activity and total phenolics of edible mushroom extracts. Food Chem, 81, 249-255

18. Zhishen J, Mengcheng T, Jianming W (1999) The determination of flavonoid contents in mulberry and their scavenging effects on superoxide radicals. Food Chem, 64, 555-559
19. Brand-Williams W, Cuvelier ME, Berset C (1995) Use of a free radical method to evaluate antioxidant activity. LWT-Food Sci Technol, 28, 25-30

20. Re R, Pellegrini N, Proteggente A, Pannala A, Yang M, Rice-Evans C (1999) Antioxidant activity applying an improved ABTS radical cation decolorization assay. Free Radical Biol Med, 26, 1231-1237

21. Marklund S, Marklund G (1974) Involvement of superoxide anion radical in the autoxidation of pyrogallol and a convenient assay for superoxide dismutase. Eur J Bidchem, 47, 468-474

22. Yang SJ, Hong JH (2015) Quality characteristics of Yanggaeng prepared with fermented blueberry by lactic acid bacteria. Korean J Food Cookery Sci, 31, 128-135

23. Liu S, Chang X, Liu X, Shen Z (2016) Effects of pretreatments on anthocyanin composition, phenolics contents and antioxidant capacities during fermentation of hawthorn (Crataegus pinnatifida) drink. Food Chem, 212, 87-95

24. Lee JY, Park YS, Kim YS, Shin DH (2002) Antimicrobial characteristics of metabolites of lactic acid bacteria isolated from feces of newborn baby and from Dongchimi. Korean J Food Sci Technol, 34, 472-479

25. Lee HJ (2013) Antioxidant activity and properties characteristics of pound cakes prepared by using frozen blueberry powder \& anthocyanin extracted from black beans. Korean J Food Nutr, 26, 772-782

26. Kim DY, Yoo SS (2017) Quality characteristics and antioxidant activities of cookies added with Gochujang. J East Asian Soc Diet Life, 27, 148-158

27. Gu YR, Kim SW, Son YEW, Hong JH (2017) Antioxidant activities of solvent extracts from different Glehnia Radix parts and their inhibitory effect against nitric oxide production in Raw 264.7 cell. Korean J Food Preserv, 24, 116-124

28. Chung HJ, Kim CJ, Choi YS (2015) Comparison of antioxidant and nitrite scavenging activities of different colored kiwis cultivated in Korea. J Korean Soc Food Cult, 30, 220-226

29. Kim MH, Jeong EJ, Kim YS (2016) Studies on the antioxidative activities and active components of the extracts from Pleurotus ostreatus. J Food Hyg Saf, 31, $119-125$ 